\title{
Estimation of native and alkylated polycyclic aromatic hydrocarbons (PAHs) in seabirds from the south coast of the Baltic Sea
}

\author{
Ilona Waszak ${ }^{1}$ (D) $\cdot$ Karolina Jonko-Sobuś $^{1} \cdot$ Agnieszka Ożarowska $^{2} \cdot$ Grzegorz Zaniewicz $^{2}$
}

Received: 12 December 2019 / Accepted: 26 August 2020 / Published online: 17 September 2020

(C) The Author(s) 2020

\begin{abstract}
Native and alkylated polycyclic aromatic hydrocarbons (PAHs) were examined in the muscle, liver, kidneys, and lungs of greater scaup (Aythya marila) and great crested grebe (Podiceps cristatus). Both species showed differences in distribution and profiles among the tissues. The highest PAH concentrations were in the scaup lungs and the grebe kidneys ( 20 and $19 \mathrm{ng} \mathrm{g}^{-1}$ wet weight, respectively). Alkylated derivatives were in the range of 61 to $77 \%$ of $\Sigma$ PAHs in both species. Differences in PAH profiles between birds, analyzed by PCA, were probably results of metabolic capability, not various diet. In comparison to available data from other regions of the world, PAH levels in investigated species are relatively low and do not pose a threat to birds themselves.
\end{abstract}

Keywords Native PAHs $\cdot$ Alkylated PAHs $\cdot$ Greater scaup $\cdot$ Great crested grebe $\cdot$ Seabirds $\cdot$ Baltic Sea

\section{Introduction}

Polycyclic aromatic hydrocarbons (PAHs) are ubiquitous and well-known environmental pollutants which have attracted a lot of scientific interest due to tendency to bioaccumulate and biomagnify in the food web. Furthermore, some of them are genotoxic, carcinogenic, and mutagenic; as a consequence, they can lead to many disorders such as reproductive dysfunction, increased susceptibility to diseases or other stresses, and changes in the behavior of animals and humans (Custer et al. 2000). PAHs never occur in the environment as individual compounds, but as a mixture of many components, including

Responsible editor: Philippe Garrigues

Electronic supplementary material The online version of this article (https://doi.org/10.1007/s11356-020-10653-y) contains supplementary material, which is available to authorized users.

Ilona Waszak

ilona.waszak@mir.gdynia.pl

1 Department of Food and Environmental Chemistry, National Marine Fisheries Research Institute (NMFRI), 1 Kołłątaja Str, 81-332 Gdynia, Poland

2 Avian Ecophysiology Unit, Department of Vertebrate Ecology and Zoology, University of Gdańsk, 59 Wita Stwosza Str, 80-308 Gdańsk, Poland hundreds of parent PAHs and their alkylated derivatives. In contrast to unsubstituted compounds, alkylated PAHs (aPAHs) are more resistant to degradation and therefore, they are longer present in the environment. Little is known about the toxic properties of aPAHs, although there are reports that they may pose a greater risk to organisms than their parent counterparts (Marvanová et al. 2008). For this reason, it is pointed out that not only PAHs but also their alkylated derivatives (EPA 2003; 2004) should be included in the environmental risk assessment.

Distribution and concentrations of PAHs in various environmental components depend on many factors. The type of source and origin determines the nature and quantity of compounds released into the environment. Although some PAHs arise from natural processes, such as forest, grass, and bush fires, volcanic eruptions, and production by microorganisms from biogenic precursors, emissions from anthropogenic activities, including combustion and processes related to use of crude oil, are considered predominant in the environment (Boitsov et al. 2009; Dalsøren et al. 2007). PAHs are widespread atmospheric pollutants (Zhou et al. 2005). The solubility of PAHs in water is low and decreases with increasing molecular weight; therefore, the concentrations of dissolved PAHs in water are very low. PAHs tend to associate with solid particles and fall to the bottom (Götz et al. 1998). Due to their stability, PAHs remain in sediments for many years, posing a threat to dwelling organisms. Therefore, monitoring programs 
of PAHs in the Baltic region mostly include research of the sediments and benthos (Lubecki and Kowalewska 2012; Namieśnik et al. 2008; Waszak et al. 2019). There is relatively little data on PAHs in seabirds. Most bird species occupy a high position in the trophic pyramids of the Baltic Sea (predators), which results in accumulation of the largest amounts of harmful substances in their tissues and organs. Therefore, birds are considered to be good bioindicators of persistent environmental pollutants such as PCBs and PBDEs, or heavy metals (Badzinski et al. 2009; Jaspers et al. 2006; TomzaMarciniak et al. 2019). However, in the case of PAHs, which are more prone to be degraded, the use of seabirds as biomonitors is still unclear and scarcely explored. Avian exposure to PAHs probably occurs mainly via oral intake of contaminated invertebrates, plants, and small fish (Kayal and Conell, 1995), but the high concentrations of PAHs in the lungs of some investigated species (Zhang et al. 2015) can also indicate inhalation of polluted air as important pathway for these compounds. Birds, like other vertebrates, generally display high oxidative P-450 enzyme activity and can quickly metabolize and easily excrete most of consumed PAHs (Näf et al. 1992; Troisi et al. 2006; Verbrugge et al. 2001). However, it has been documented that there is a relationship between the presence of PAHs in bird tissues and petroleum contamination of surface water (Custer et al. 2000). The yellow-legged gull (Larus michahellis) was suggested as a good indicator of PAH contamination after comparing levels from colonies polluted by the Prestige oil spill with nonaffected areas (Pérez et al. 2008).

In the present study, the PAH concentrations were measured in two species of seabirds, greater scaup (Aythya marila) and great crested grebe (Podiceps cristatus), from the two areas of south coast of the Baltic Sea, Pomeranian Bay (PB) and Szczecin Lagoon (SL). These two species of birds differ in diet. The scaup's basic food is benthos, represented by zebra mussel (Dreissena polymorpha) in the SL area (Marchowski et al. 2015), and by sand gaper (Mya arenaria), blue mussel (Mytilus edulis), and baltic clam (Macoma balthica) in the maritime zone (PB) (Mendel et al. 2008; Stempniewicz and Meissner 1999). The grebe favors a fish-based diet (Ulenaers and Vessem 1994), where smelt (Osmerus eperlanus) predominates and some benthic fishes, e.g., flounder (Platichthys flesus), appear less frequently (Morkune et al. 2016; Piersma et al. 1988). The area from which the scaup and grebe samples were collected is one of the most important wintering location for many native and arctic species of birds, where coastal waters are characterized by an abundant food supply. However, this is an area under strong anthropogenic pressure, which is influenced by maritime economy with some important sea routes for ships, numerous ports and repair shipyards, the fuel and energy industry, and mining (crude oil). In the aspect of these issues, the present study investigates the levels, distribution, and potential sources of PAHs in the seabirds from the south coast of the Baltic Sea, to gain a better understanding of the interspecies differences and their routes of exposure.

\section{Materials and methods}

\section{Sampling strategy}

Eleven specimens of the two bird species were selected for the study (Table 1). The examination concerned only individuals which were found dead in fishing nets. None of them was killed for the purpose of performing this study. All birds were obtained from the area covering the part of Pomeranian Bay, PB $\left(53^{\circ} 55-56^{\prime} \mathrm{N}, 14^{\circ} 14-19^{\prime} \mathrm{E}\right)$, and the area of Szczecin Lagoon, SL $\left(53^{\circ} 42-51^{\prime} \mathrm{N}, 14^{\circ} 16-26^{\prime} \mathrm{E}\right)$, during winter 2014-2015 (Fig. 1). The biological parameters of the birds, i.e., physical condition, gender (male, $\mathrm{M}$ vs female, $\mathrm{F}$ ), age, and body mass, were evaluated. The $2 \mathrm{M}$ and $3 \mathrm{~F}$ of scaup and only $1 \mathrm{~F}$ of grebe were obtained from $\mathrm{PM}$, while $3 \mathrm{M}$ and $3 \mathrm{~F}$ of scaup and $6 \mathrm{M}$ and 4F of grebe were from SL. Only specimens aged 2 years (or slightly above) in good condition were taken to the section. The breast muscles, liver, kidneys, and lungs were freeze-dried and stored at $-20^{\circ} \mathrm{C}$ until analysis.

\section{Preparation of samples for analysis}

For PAH analyses, the all tissues were extracted with a mixture of n-hexane: dichloromethane (DCM) $(1: 1, v / v)$ using a fully automated ASE 350 system (Dionex, Sunnyvale, CA, USA). Ten percent $(v / v)$ of the extract was taken for the lipid content determination. The volume containing $0.3 \mathrm{~g}$ of lipid from the remaining part of the extract was dissolved in $10 \mathrm{ml}$ of n-hexane and supplemented with surrogate standards (SS, acenaphthene- $\mathrm{d}_{10}$, chrysene- $\mathrm{d}_{12}$, naphthalene- $\mathrm{d}_{8}$, phenanthrene- $\mathrm{d}_{10}$, and perylene- $\mathrm{d}_{12}$ ). After adding $10 \mathrm{ml}$ of $\mathrm{KOH}$ ( $0.5 \mathrm{M}$ solution in $\mathrm{MeOH}: \mathrm{H}_{2} \mathrm{O}, 1: 1, \mathrm{v} / \mathrm{v}$ ), the mixture was gently mixed and then centrifuged at $2000 \mathrm{rpm}$ for $40 \mathrm{~min}$. After centrifugation, the n-hexane layer (containing the compounds of interest) was transferred into a flask and the separation procedure was repeated two more times with aliquots of $10 \mathrm{ml}$-hexane. The obtained extracts were combined and concentrated using a rotatory evaporator to about $1 \mathrm{ml}$, and then loaded on a glass column (5 $\mathrm{g}$ of $5 \%$ deactivated silica gel), and the compounds were eluted with $100 \mathrm{ml}$ of $\mathrm{n}$ hexane:DCM $(95: 5 \%, \mathrm{v} / \mathrm{v})$. This extract was concentrated, solvent exchanged to isooctane, transferred to a glass vial, and reconstituted using a gentle nitrogen stream to a final volume of $0.2 \mathrm{ml}$. The lipid content in tissues was determined gravimetrically on an aliquot of the extract for each sample. 
Table 1 Biological characteristics of birds from the southern Baltic Sea (values are mean with the range of results)

\begin{tabular}{|c|c|c|c|c|c|c|c|}
\hline \multirow[t]{2}{*}{ Species } & \multirow[t]{2}{*}{ Gender } & \multirow[t]{2}{*}{$N^{1}$} & \multirow[t]{2}{*}{ Body mass (g) } & \multicolumn{4}{|l|}{ Lipids $(\%)^{2}$} \\
\hline & & & & Muscle & Liver & Kidneys & Lungs \\
\hline \multirow[t]{2}{*}{ Greater scaup (Aythya marila) } & Male & 5 & $1312(1128-1460)$ & $3.6(2.9-5.2)$ & $3.2(2.5-4.1)$ & $5.0(2.7-6.9)$ & $2.3(1.7-3.4)$ \\
\hline & Female & 6 & $1156(1016-1303)$ & $3.8(3.3-4.3)$ & $3.1(2.7-3.4)$ & $3.1(2.1-5.8)$ & $1.7(1.4-2.3)$ \\
\hline \multirow[t]{2}{*}{ Great crested grebe (Podiceps cristatus) } & Male & 5 & $1429(1204-1551)$ & $5.0(2.2-8.3)$ & $3.6(2.5-5.5)$ & $3.9(3.4-4.9)$ & $2.5(1.9-3.3)$ \\
\hline & Female & 6 & $1237(1104-1405)$ & $4.5(3.2-6.4)$ & $3.2(2.9-5.6)$ & $3.5(2.9-4.9)$ & $2.4(1.5-3.5)$ \\
\hline
\end{tabular}

${ }^{1}$ The number of specimens. ${ }^{2}$ The lipid content (\%) in wet weight of tissue

\section{GC-MS analysis}

The method of analysis was based on the Waszak et al. (2019), Ibadov and Suleymanov (2015), and Martinez et al. (2004) guidelines with some modifications. Analyses were performed using gas chromatography-mass spectrometry (GCMS) with a 30-m DB-5MS column. The sample injection, transfer line, and ion source temperatures were $290{ }^{\circ} \mathrm{C}$, $280{ }^{\circ} \mathrm{C}$, and $200{ }^{\circ} \mathrm{C}$, respectively. The column temperature was initially held at $40^{\circ} \mathrm{C}$ for 1 min and gradually raised to $120{ }^{\circ} \mathrm{C}$ at the rate of $25^{\circ} \mathrm{C} \mathrm{min}^{-1}$, then to $160{ }^{\circ} \mathrm{C}$ at $10{ }^{\circ} \mathrm{C} \mathrm{min}{ }^{-1}$, and finally to $300{ }^{\circ} \mathrm{C}$ at $5{ }^{\circ} \mathrm{C} \min ^{-1}$, and held for $15 \mathrm{~min}$. The total analysis time was $51.2 \mathrm{~min}$. Helium, as the carrier gas, had a constant flow rate of $1 \mathrm{ml} \mathrm{min}^{-1}$. Mass spectrometry was performed using electron ionization (EI) and selective ion monitoring (SIM) mode. The compounds were identified based on retention times and mass spectra. Their concentrations were calculated referring to isotopelabeled standards (SS) recovery (SupData; Table 1). The range of retention times of PAH derivatives was established based on crude oil sample analysis (e.g., Diesel Fuel \#2 dissolved in DCM). The following compounds were analyzed: 16 unsubstituted PAHs recommended by the US EPA: acenaphthene (Ace), acenaphthylene (Acy), anthracene (Ant), benzo[a]anthracene $(\mathrm{B}[\mathrm{a}] \mathrm{A})$, benzo[b]fluoranthene $(\mathrm{B}[\mathrm{b}] \mathrm{F})$, benzo[k]fluoranthene $(\mathrm{B}[\mathrm{k}] \mathrm{F})$, benzo[ghi]perylene $(\mathrm{B}[\mathrm{ghi}] \mathrm{P})$, benzo[a]pyrene $(\mathrm{B}[\mathrm{a}] \mathrm{P})$, chrysene $(\mathrm{Chr})$, dibenzo[a,h]anthracene (DB[ah]A), fluoranthene (Flt), fluorene (Flu), indeno[1,2,3-cd]pyrene (I[cd]P), naphthalene (Naph), phenanthrene (Phe), and pyrene (Pyr), and alkylated

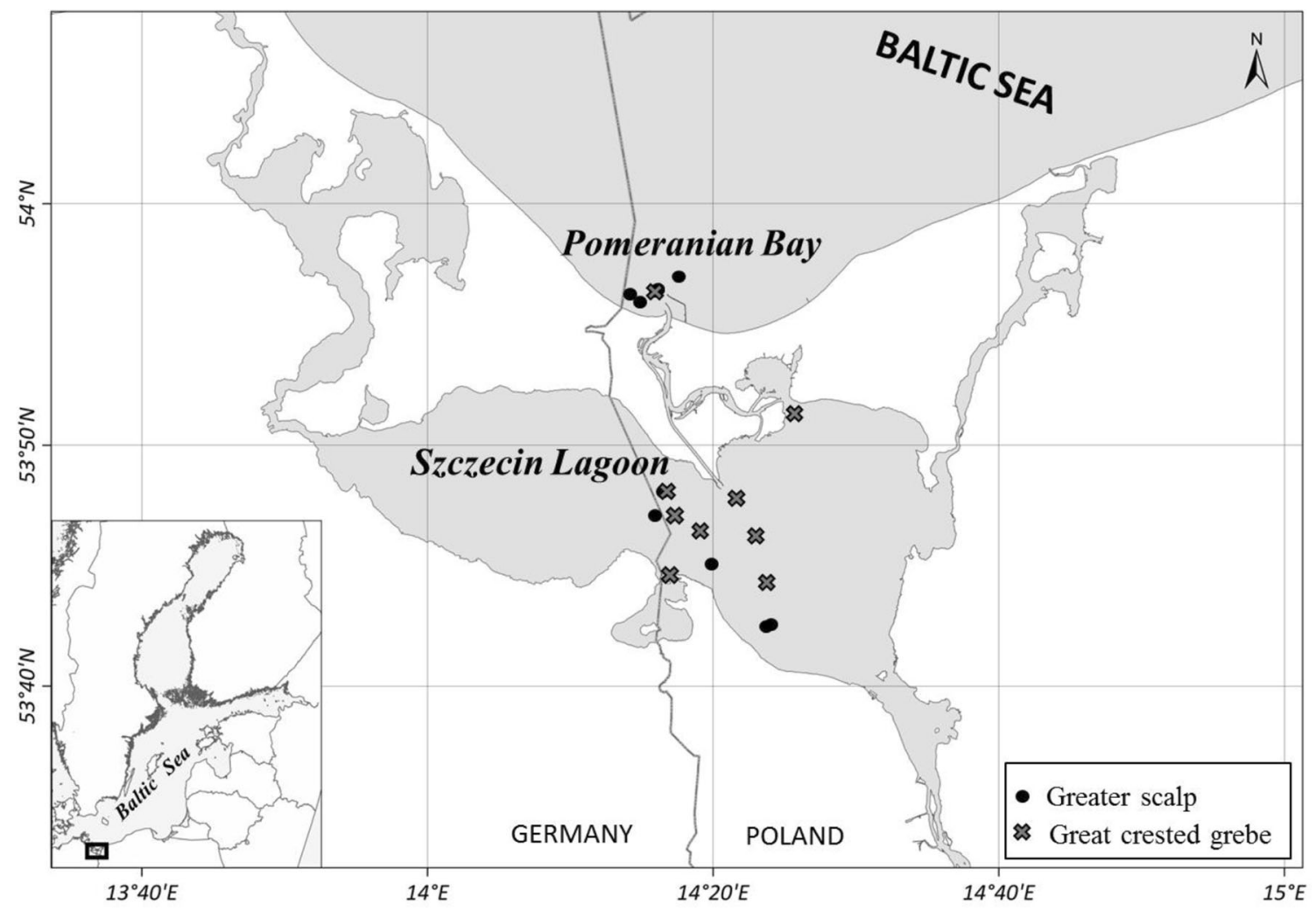

Fig. 1 The bird sampling collections in the southern Baltic Sea 
derivatives of naphthalene (C1-, C2-, C3-Naph), phenanthrene and anthracene ( $\mathrm{C} 1-$ and $\mathrm{C} 2$-Phe/Ant), and dibenzothiophene (C1- and $\mathrm{C} 2-\mathrm{DBT})$. The concentrations of individual PAHs were summed as follows: $\Sigma_{16} \mathrm{PAHs}$ (16 unsubstituted PAHs), $\Sigma$ 3-ring PAHs (Ace, Acy, Flu, Phe, and Ant), $\Sigma$ 4-ring PAHs (Flt, Pyr, B[a]A, and Chr), $\Sigma 5$-ring PAHs (B[b]F, B[k]F, B[a]P, and DB[ah]A), and $\Sigma 6$-ring PAHs (I[cd]P and B[ghi]P), $\mathrm{\Sigma aPAHs}(\mathrm{C} 1-, \mathrm{C} 2-$, and C3Naph; C1-, C2-Phe/Ant, and C1-, C2-DBT), EPAHs ( $\Sigma_{16} \mathrm{PAHs}$ and $\Sigma$ aPAHs). The limit of detection (LOD) for individual PAHs was $0.01 \mathrm{ng} \mathrm{g}^{-1}$ wet weight (ww) (Table 2). Quality control included procedural blanks (SupData; Table 2), duplicates, standard analysis, and recovery of surrogate standards added to each sample and blanks. The average recovery of SS was from 67 to $166 \%$ (SupData; Table 3). The PAH concentrations in tissues were blank- and SS-recoverycorrected.

\section{Statistical analysis}

Statistical analysis of the data was performed using the Statistica 10.0 (StatSoft Inc., Tulsa, OK, USA). Prior to the analyses, the distribution of the data was determined using the Shapiro-Wilk $W$ test. Differences in biological parameters between $\mathrm{M}$ and $\mathrm{F}$ of each specimens, as well as between scaups and grebes, were examined with either $t$ test or Mann-Whitney test, depending on whether or not assumption of normality and homogeneity of variance was met. These both statistic tests was also used to examine PAH concentrations in tissues ( $\Sigma 3-, 4-, 5-$, and 6-ring PAHs, $\Sigma_{16} \mathrm{PAHs}, \Sigma \mathrm{PPAHs}$, and $\Sigma$ PAHs) between both species. Intraspecies differences in the PAH concentrations among the tissues were examined with either ANOVA (Tukey test with HSD) or KruskalWallis test. If more than $50 \%$ of the observations were with PAH levels below LOD, no statistical analyses were conducted. For the other observations with PAH concentrations below LOD, a value of LOD/2 was assigned for the statistical analysis. Relationships between biological parameters (body mass and tissue lipid content) and PAH concentrations were evaluated using regression analysis in a general linear model (GLM) or the nonparametric Spearman test. The birds did not differ sexually due to biological parameters and PAH concentrations within each species (Table 1); therefore, males and females were consider as a one group (scaups or grebes) in this study. All results were given as means and their standard deviations.

\section{Results and discussion}

To our knowledge, this is the first study in which PAH concentrations have been evaluated in birds from the Pomeranian Bay and Szczecin Lagoon on the south cost of the Baltic Sea.
The present study results suggest that PAHs in bird, despite of the metabolic capacity, are found in their tissues. The PAH levels differed between both analyzed species and among tissues within the same species as well.

\section{Greater scaup}

The mean concentration of $\Sigma_{16} \mathrm{PAHs}, \Sigma \mathrm{aPAHs}$, and $\Sigma$ PAHs in scaup differed significantly among tissues and based on wet weight, it was in the range of 1.5-6.4, 4.0-13, and 5.5$20 \mathrm{ng} \mathrm{g}^{-1}$, respectively, whereas lipid-normalized concentrations were in the range of $41-380,80-779$, and121$1159 \mathrm{ng} \mathrm{g}^{-1}$, respectively (Table 2). $\Sigma$ aPAHs constituted $66-77 \%$ of $\Sigma \mathrm{PAHs}$ and had the greatest contribution in the liver and kidneys (Fig. 2a). The highest wet weight and lipidnormalized concentration of all analyzed group of compounds occurred in the lungs, followed by the liver and kidneys. Compared with the literature, the $\Sigma_{16} \mathrm{PAH}$ and $\Sigma \mathrm{PAH}$ levels in all the tissues were lower than those previously reported in birds from other regions, with exception of the similar levels of $\Sigma_{16} \mathrm{PAHs}$ in the scaup liver and those reported in Procellariiformes from the Mediterranean Sea. In relation to contaminated area, the concentrations were up to an order of magnitude lower than those observed in the liver of oiled common guillemots (Uria aalge) stranded on the east coast of England (Table 3). Like the PAH concentrations, their composition varied significantly among the scaup tissues as well. Among native compounds, the dominants in the muscle, liver, and kidneys were 3-ring PAHs with contribution of 47-73\% of $\Sigma_{16} \mathrm{PAHs}$, whereas in the lungs 2-ring PAHs dominated (74\% of $\Sigma_{16}$ PAHs; Fig. $2 \mathrm{c}$ ). The dominant individual compound in the muscle and liver was Phe (54\% and 30\% of $\Sigma_{16} \mathrm{PAHs}$, respectively), but in the kidneys and lungs, it was Naph (37\% and $73 \%$ of $\Sigma_{16}$ PAHs, respectively) followed by Phe (31\% and $11 \%$ of $\Sigma_{16} \mathrm{PAHs}$, respectively) (Table 2). Among alkylated compounds, C1-C3-Naph dominated in all tissues (58-93\% of $\Sigma$ aPAHs), but it was significantly high fraction of them in the lungs (Fig. 2e). This high proportion of Naph and its alkylated homologs in relation to other analyzed compounds in the lungs resulted in this organ characterized by the highest $\Sigma$ PAH concentrations among all examined tissues. Although in most of the literature, PAH profiles in seabird differed among species and their tissues, Roscales et al. (2011) found the similar $\Sigma_{16}$ PAHs profile in the liver of two species of petrel (Bulweria bulwerii and Pelagodroma marina) from Atlantic, in which 3-ring PAHs dominated and 5-6-ring PAHs had the smallest contribution. The same authors reported that the most abundant compound in the petrel liver was Flt, followed by Naph. With regard to aPAH profiles, so far the less frequently analyzed, alkyl naphthalenes (C1-C4-Naph) were stated as dominants in fat tissues of penguin (Pygoscelis sp.) and skula (Catharacta antarctica) from King George Island (Antarctica) (Taniguchi et al. 2009). 
Table 2 Concentrations of native and alkylated PAHs in birds from the southern Baltic Sea (ng g ${ }^{-1}$ ww; mean and standard deviations)

\begin{tabular}{|c|c|c|c|c|c|c|c|c|}
\hline & \multicolumn{4}{|l|}{ Greater scaup } & \multicolumn{4}{|c|}{ Great crested grebe } \\
\hline & Muscle & Liver & Kidneys & Lungs & Muscle & Liver & Kidneys & Lungs \\
\hline \multicolumn{9}{|l|}{ 16PAHs } \\
\hline Naph & $0.2 \pm 0.1$ & $0.7 \pm 0.5$ & $1.0 \pm 0.2$ & $4.7 \pm 1.2$ & $0.8 \pm 0.3$ & $1.0 \pm 0.4$ & $2.9 \pm 2.0$ & $3.7 \pm 2.0$ \\
\hline Acy & $0.04 \pm 0.01$ & $0.05 \pm 0.04$ & $0.07 \pm 0.03$ & $0.03 \pm 0.02$ & $0.1 \pm .0 .06$ & $0.04 \pm 0.01$ & $0.2 \pm 0.1$ & $0.04 \pm 0.03$ \\
\hline Ace & $0.05 \pm 0.01$ & $0.09 \pm 0.03$ & $0.2 \pm 0.1$ & $0.1 \pm 0.05$ & $0.1 \pm 0.03$ & $0.09 \pm 0.03$ & $0.2 \pm 0.01$ & $0.2 \pm 0.1$ \\
\hline Flu & $0.2 \pm 0.1$ & $0.2 \pm 0.1$ & $0.3 \pm 0.2$ & $0.2 \pm 0.1$ & $0.3 \pm 0.1$ & $0.1 \pm 0.06$ & $0.5 \pm 0.4$ & $0.2 \pm 0.04$ \\
\hline Phe & $0.8 \pm 0.3$ & $0.8 \pm 0.7$ & $0.8 \pm 0.4$ & $0.7 \pm 0.5$ & $0.9 \pm 0.6$ & $0.5 \pm 0.3$ & $2.3 \pm 1.5$ & $0.7 \pm 0.2$ \\
\hline Ant & $0.03 \pm 0.01$ & $0.03 \pm 0.02$ & $0.02 \pm 0.01$ & $0.02 \pm 0.01$ & $0.06 \pm 0.01$ & $0.04 \pm 0.02$ & $0.04 \pm 0.01$ & $0.02 \pm 0.01$ \\
\hline Flt & $0.3 \pm 0.1$ & $0.3 \pm 0.2$ & $0.3 \pm 0.1$ & $0.2 \pm 0.1$ & $0.2 \pm 0.1$ & $0.3 \pm 0.2$ & $0.6 \pm 0.4$ & $0.2 \pm 0.1$ \\
\hline Pyr & $0.2 \pm 0.1$ & $0.2 \pm 0.1$ & $0.3 \pm 0.2$ & $0.2 \pm 0.1$ & $0.2 \pm 0.03$ & $0.2 \pm 0.1$ & $0.6 \pm 0.3$ & $0.2 \pm 0.1$ \\
\hline $\mathrm{B}(\mathrm{a}) \mathrm{A}$ & nd & $0.03 \pm 0.1$ & nd & $0.01 \pm 0.003$ & $0.05 \pm 0.03$ & $0.07 \pm 0.02$ & $0.08 \pm 0.02$ & $0.01 \pm 0.003$ \\
\hline $\mathrm{Chr}$ & $0.04 \pm 0.01$ & $0.08 \pm 0.05$ & $0.05 \pm 0.02$ & $0.06 \pm 0.02$ & $0.07 \pm 0.05$ & $0.1 \pm 0.03$ & $0.04 \pm 0.01$ & $0.02 \pm 0.01$ \\
\hline $\mathrm{B}(\mathrm{b}) \mathrm{F}$ & nd & nd & $0.04 \pm 0.01$ & $0.05 \pm 0.01$ & $0.06 \pm 0.02$ & $0.4 \pm 0.1$ & $0.08 \pm 0.03$ & $0.04 \pm 0.01$ \\
\hline $\mathrm{B}(\mathrm{k}) \mathrm{F}$ & nd & nd & nd & nd & nd & nd & $0.2 \pm 0.1$ & nd \\
\hline $\mathrm{B}(\mathrm{a}) \mathrm{P}$ & nd & nd & nd & nd & $0.2 \pm 0.1$ & nd & $0.1 \pm 0.05$ & nd \\
\hline $\mathrm{I}(\mathrm{cd}) \mathrm{P}$ & $0.03 \pm 0.01$ & $0.04 \pm 0.02$ & $0.07 \pm 0.03$ & $0.02 \pm 0.01$ & $0.06 \pm 0.01$ & $0.3 \pm 0.2$ & $0.06 \pm 0.04$ & $0.01 \pm 0.002$ \\
\hline DB(ah)A & $0.04 \pm 0.01$ & $0.03 \pm 0.01$ & $0.1 \pm 0.03$ & nd & $0.08 \pm 0.03$ & $0.3 \pm 0.1$ & $0.07 \pm 0.03$ & nd \\
\hline B(ghi)P & nd & $0.03 \pm 0.02$ & nd & nd & $0.05 \pm 0.01$ & $0.2 \pm 0.1$ & $0.03 \pm 0.01$ & nd \\
\hline \multicolumn{9}{|l|}{ aPAHs } \\
\hline C1-Naph & $0.7 \pm 0.2$ & $3.0 \pm 0.8$ & $2.0 \pm 0.7$ & $8.5 \pm 2.2$ & $1.8 \pm 0.6$ & $1.9 \pm 0.9$ & $3.0 \pm 1.0$ & $4.5 \pm 2.2$ \\
\hline C2-Naph & $0.8 \pm 0.5$ & $1.4 \pm 0.8$ & $1.5 \pm 0.7$ & $2.1 \pm 1.0$ & $1.3 \pm 0.5$ & $1.3 \pm 0.6$ & $2.5 \pm 1.6$ & $1.4 \pm 0.5$ \\
\hline C3-Naph & $0.8 \pm 0.3$ & $1.5 \pm 1.0$ & $1.0 \pm 0.5$ & $1.5 \pm 1.1$ & $1.5 \pm 0.7$ & $1.1 \pm 0.4$ & $2.4 \pm 1.0$ & $1.0 \pm 0.4$ \\
\hline C1-Phe/Ant & $0.9 \pm 0.4$ & $1.1 \pm 0.8$ & $1.9 \pm 0.9$ & $0.5 \pm 0.3$ & $2.5 \pm 1.1$ & $0.9 \pm 0.5$ & $2.3 \pm 1.6$ & $0.6 \pm 0.2$ \\
\hline C2-Phe/Ant & $0.7 \pm 0.3$ & $1.3 \pm 0.8$ & $0.7 \pm 0.5$ & $0.4 \pm 0.1$ & $2.0 \pm 0.9$ & $1.1 \pm 0.7$ & $2.2 \pm 1.5$ & $0.5 \pm 0.1$ \\
\hline C1-DBT & $0.2 \pm 0.1$ & $0.4 \pm 0.3$ & $0.3 \pm 0.2$ & $0.2 \pm 0.1$ & $0.4 \pm 0.1$ & $0.5 \pm 0.3$ & $0.4 \pm 0.3$ & $0.3 \pm 0.1$ \\
\hline C2-DBT & $0.3 \pm 0.2$ & $1.3 \pm 0.5$ & $0.4 \pm 0.3$ & $0.1 \pm 0.03$ & $1.0 \pm 0.6$ & $0.8 \pm 0.5$ & $0.6 \pm 0.3$ & $0.2 \pm 0.1$ \\
\hline 3-ring PAHs & $1.1 \pm 0.5$ & $1.2 \pm 0.7$ & $1.3 \pm 0.6$ & $1.1 \pm 0.5$ & $1.5 \pm 0.9$ & $0.8 \pm 0.3$ & $3.2 \pm 2.2$ & $1.1 \pm 0.5$ \\
\hline 4-ring PAHs & $0.4 \pm 0.3$ & $0.6 \pm 0.3$ & $0.6 \pm 0.3^{\mathrm{A}}$ & $0.5 \pm 0.1$ & $0.4 \pm 0.1$ & $0.5 \pm 0.2$ & $1.2 \pm 0.8^{\mathrm{B}}$ & $0.4 \pm 0.2$ \\
\hline 5-ring PAHs & $0.01 \pm 0.008^{\mathrm{A}}$ & $0.01 \pm 0.006^{\mathrm{A}}$ & $0.02 \pm 0.01^{\mathrm{A}}$ & $0.05 \pm 0.03$ & $0.3 \pm 0.2^{\mathrm{B}}$ & $0.3 \pm 0.2^{\mathrm{B}}$ & $0.3 \pm 0.1^{\mathrm{B}}$ & $0.04 \pm 0.01^{\mathrm{a}}$ \\
\hline 6-ring PAHs & $0.01 \pm 0.006^{\mathrm{A}}$ & $0.03 \pm 0.01^{\mathrm{A}}$ & $0.01 \pm 0.006$ & $0.02 \pm 0.005$ & $0.1 \pm 0.04^{\mathrm{a}, \mathrm{B}}$ & $0.5 \pm 0.3^{\mathrm{b}, \mathrm{B}}$ & $0.02 \pm 0.01^{\mathrm{ac}}$ & $0.02 \pm 0.01^{\mathrm{c}}$ \\
\hline${ }_{16} \mathrm{PAHs}^{1}$ & $1.5 \pm 0.9^{\mathrm{a}}$ & $2.5 \pm 2.0^{\mathrm{ab}}$ & $2.6 \pm 1.8^{\mathrm{ab}, \mathrm{A}}$ & $6.4 \pm 2.1^{\mathrm{b}}$ & $2.7 \pm 1.9^{\mathrm{a}}$ & $2.8 \pm 1.9^{\mathrm{a}}$ & $7.3 \pm 5.5^{\mathrm{b}, \mathrm{B}}$ & $5.2 \pm 3.1^{\mathrm{ab}}$ \\
\hline $\mathrm{aPAHs}^{2}$ & $4.0 \pm 1.5^{\mathrm{a}, \mathrm{A}}$ & $9.1 \pm 4.3^{\mathrm{ab}}$ & $7.2 \pm 2.5^{\mathrm{a}, \mathrm{A}}$ & $13 \pm 4.1^{b}$ & $8.9 \pm 5.3^{\mathrm{B}}$ & $7.5 \pm 3.5$ & $11 \pm 3^{\mathrm{B}}$ & $8.4 \pm 3.7$ \\
\hline $\mathrm{PAHs}^{3}$ & $5.5 \pm 0.8^{\mathrm{a}, \mathrm{A}}$ & $12 \pm 4.1^{\mathrm{ab}}$ & $9.3 \pm 3.0^{\mathrm{a}, \mathrm{A}}$ & $20 \pm 3.6^{\mathrm{b}}$ & $12 \pm 5.0^{\mathrm{a}, \mathrm{B}}$ & $10 \pm 7.0^{\mathrm{a}}$ & $19 \pm 7.1^{\mathrm{b}, \mathrm{B}}$ & $14 \pm 6.2^{\mathrm{ab}}$ \\
\hline aPAHs $(\%)^{4}$ & 73 & 76 & 77 & 66 & 77 & 73 & 61 & 62 \\
\hline${ }_{16} \mathrm{PAHs}^{5}$ & $41 \pm 9.1^{\mathrm{a}}$ & $80 \pm 50^{\mathrm{ab}}$ & $79 \pm 29^{\mathrm{b}, \mathrm{A}}$ & $380 \pm 101^{\mathrm{c}, \mathrm{A}}$ & $56 \pm 13^{\mathrm{a}}$ & $86 \pm 52^{\mathrm{ab}}$ & $210 \pm 152^{\mathrm{bc}, \mathrm{B}}$ & $214 \pm 129^{\mathrm{c}, \mathrm{B}}$ \\
\hline $\mathrm{aPAHs}^{5}$ & $80 \pm 32^{\mathrm{a}, \mathrm{A}}$ & $322 \pm 95^{\mathrm{b}}$ & $153 \pm 65^{\mathrm{a}, \mathrm{A}}$ & $779 \pm 479^{\mathrm{c}, \mathrm{A}}$ & $176 \pm 70^{\mathrm{a}, \mathrm{B}}$ & $230 \pm 92^{\mathrm{ab}}$ & $366 \pm 93^{\mathrm{b}, \mathrm{B}}$ & $381 \pm 142^{\mathrm{b}, \mathrm{B}}$ \\
\hline $\mathrm{PAHs}^{5}$ & $121 \pm 35^{\mathrm{a}, \mathrm{A}}$ & $402 \pm 122^{\mathrm{b}}$ & $232 \pm 84^{\mathrm{c}, \mathrm{A}}$ & $1159 \pm 236^{\mathrm{d}, \mathrm{A}}$ & $232 \pm 76^{\mathrm{a}, \mathrm{B}}$ & $315 \pm 210^{\mathrm{ab}}$ & $573 \pm 221^{\mathrm{b}, \mathrm{B}}$ & $601 \pm 252^{\mathrm{b}, \mathrm{B}}$ \\
\hline
\end{tabular}

${ }^{1}$ The sum of 16 native PAHs. ${ }^{2}$ The sum of alkylated PAHs derivatives. ${ }^{3}$ The sum of native and alkylated PAHs. ${ }^{4}$ aPAHs expressed as the percentage (\%) of PAHs. ${ }^{5}$ Concentration in $\mathrm{ng} \mathrm{g}^{-1}$ lipid. ${ }^{\mathrm{a}-\mathrm{d}}$ Significant intraspecies differences among PAH concentrations in tissues. ${ }^{\mathrm{A}, \mathrm{B}}$ Significant interspecies differences in PAHs concentrations. $n d$, the concentration below the detection limit

Regression analysis of wet weight concentration of $\Sigma_{16} \mathrm{PAHs}$ in each tissue versus scaup body mass indicated no significant relationships between all these variables. However, $\Sigma_{16} \mathrm{PAH}$ concentration was significantly related to lipid content in the muscle and lungs $(p<0.03)$, but not in the liver and kidneys. For $\mathrm{\Sigma aPAHs}$, the concentration only in the muscle was significantly related to bird body mass $(p=0.004)$ and not correlated with lipid content in any tissue. In the literature reviewed, no previous studies were found on the relationship between PAH content in aquatic birds and their body mass (length) or lipid content. 
Table 3 Native and alkylated PAH concentrations in seabirds around the word ( $\mathrm{ng} \mathrm{g}^{-1} \mathrm{ww}$, mean and the range of values)

\begin{tabular}{|c|c|c|c|c|c|c|}
\hline Site & Year & Species & Tissue & PAHs group & Concentrations & References \\
\hline $\begin{array}{l}\text { South cost of the } \\
\text { Baltic Sea }\end{array}$ & 2014-2015 & $\begin{array}{l}\text { Greater scaup } \\
\qquad(\text { Aythya marila }) \\
\text { Great crested grebe } \\
\quad \text { (Podiceps cristatus) }\end{array}$ & $\begin{array}{l}\text { Muscle } \\
\text { Liver } \\
\text { Kidneys } \\
\text { Lungs } \\
\text { Muscle } \\
\text { Liver } \\
\text { Kidneys } \\
\text { Lungs }\end{array}$ & $\begin{array}{l}\sum_{16} \mathrm{PAHs}, \mathrm{C} 1-\mathrm{C} 3-\mathrm{Naph} \\
\text { C1-C2-Phe/Ant, } \\
\text { C1-C2-DBT }\end{array}$ & $\begin{array}{l}4.5(2.0-6.7) \\
11(6.4-16) \\
7.3(5.1-11) \\
20(13-23) \\
12(6.8-17) \\
10(7.2-17) \\
19(12-26) \\
14(9.8-20)\end{array}$ & This study \\
\hline $\begin{array}{l}\text { Gulf of Gdańsk, } \\
\text { Baltic Sea }\end{array}$ & 2010-2012 & $\begin{array}{l}\text { Herring gulls } \\
\quad \text { (Larus argentatus) }\end{array}$ & Lungs & $\sum_{5} \mathrm{PAHs}$ & $4.6-115^{*}$ & $\begin{array}{l}\text { Falkowska et al. } \\
\text { (2017) }\end{array}$ \\
\hline Northern Baltic proper & 1990 & $\begin{array}{l}\text { Common eider } \\
\quad \text { (Somateria mollissima) }\end{array}$ & $\begin{array}{l}\text { Liver } \\
\text { Kidney }\end{array}$ & $\Sigma_{16} \mathrm{PAHs}$ & $\begin{array}{l}24 \\
18\end{array}$ & Näf et. al (1992) \\
\hline $\begin{array}{l}\text { Brisbane River estuary } \\
\text { (Australia) }\end{array}$ & 1988 & $\begin{array}{l}\text { Pelican (Pelecanus } \\
\text { conspicillatus) } \\
\text { Silver gull (Larus } \\
\text { novaehollandiae) }\end{array}$ & Muscle & $\Sigma_{8} \mathrm{PAHs}, \mathrm{C} 2-\mathrm{Naph}$ & $\begin{array}{l}75 \\
85\end{array}$ & $\begin{array}{l}\text { Kayal and Connell } \\
\text { (1995) }\end{array}$ \\
\hline $\begin{array}{l}\text { Indiana Harbor Canal } \\
\text { (East Chicago, USA) }\end{array}$ & 1994 & $\begin{array}{l}\text { Lesser scaup } \\
\text { (Aythya affinis) }\end{array}$ & Carcasses & $\begin{array}{l}\text { Naph, Phe, B(a)P, } \\
\text { C1-Naph }\end{array}$ & $115(95-135)$ & $\begin{array}{l}\text { Custer et al. } \\
\quad(2000)\end{array}$ \\
\hline East coast of England & $2001-2002$ & $\begin{array}{l}\text { Common guillemots } \\
\text { (Uria alge) }\end{array}$ & Liver & $\Sigma_{10}$ PAHs & $245(43-972)$ & Troisi et. al (2006) \\
\hline $\begin{array}{l}\text { Northeast Atlantic } \\
\text { Mediterranean Sea }\end{array}$ & $2003-2007$ & $\begin{array}{l}5 \text { species of } \\
\text { Procellariiformes }\end{array}$ & Liver & $\Sigma_{15} \mathrm{PAHs}$ & $\begin{array}{l}24(3.3-66) \\
5.8(1.5-10)\end{array}$ & $\begin{array}{l}\text { Roscales et. al } \\
\text { (2011) }\end{array}$ \\
\hline
\end{tabular}

*Concentration in $\mathrm{ng} \mathrm{g}^{-1}$ dry weight.

\section{Great crested grebe}

The wet weight concentration of $\Sigma_{16} \mathrm{PAHs}, \Sigma \mathrm{aPAHs}$, and $\Sigma$ PAHs in grebe tissues, in the range of 2.2-7.3, 7.5-11, and 10-19 $\mathrm{ng} \mathrm{g}^{-1}$, respectively, as well as the lipid-based concentration in the range of 56-214, 176-381, and 232-601 $\mathrm{ng} \mathrm{g}^{-1}$, respectively, showed significant differences (Table 2). $\Sigma$ aPAHs constituted $61-77 \%$ of $\Sigma \mathrm{PAH}$ levels and had the greatest contribution in the muscle (Fig. 2a). The highest PAH wet weight concentrations occurred in the kidneys, although they were nearly two times lower than those reported in the kidneys of common eider from the northern Baltic (Table 3). Similarly, the PAH wet weight levels in the other grebe tissues were relatively lower than in different bird species from the other sites documented in the literatures. PAH levels in grebe expressed in lipid content were the highest in the lungs and kidneys (Table 2). Composition of parent PAHs differed significantly among tissues with the greatest contribution of 3-ring PAHs in the muscle and kidneys (42-56\% of $\Sigma_{16} \mathrm{PAHs}$ ) and 2-ring PAHs in the liver and lungs (36-70\% of $\Sigma_{16} \mathrm{PAHs}$ ) (Fig. 2d). There were also visible differences in 6ring $\mathrm{PAH}$ share, in which contribution was relatively high in the liver (18\% of $\Sigma_{16} \mathrm{PAHs}$ ) compared with that in other tissues (less than 2\%). The dominant compounds in the muscle and kidneys were Naph and Phe (30-40\% of $\left.\Sigma_{16} \mathrm{PAHs}\right)$, but in the liver and lungs, it was Naph $(36 \%$ and $71 \%$ of $\Sigma_{16} \mathrm{PAHs}$, respectively) (Table 2). In comparison to available literature data, among five bird species, only the liver of piscivorous shearwater (Calonectris borealis) from the Atlantic had the similar $\Sigma_{16} \mathrm{PAH}$ profiles, in which 2-ring PAHs dominated and Naph was the most abundant compound (Roscales et al. 2011). Furthermore, 5- and 6-ring PAHs had the same contribution in the profiles (about $5 \%$ of $\Sigma_{16} \mathrm{PAHs}$ ) in contrast to the other species. Alkylated PAH profiles in all tissues were fairly similar with the dominant group being $\mathrm{C1}$ C3-Naph (52-83\% of $\Sigma$ aPAHs); however, the lungs showed relatively the greatest percentage of alkylated naphthalenes in comparison with the other tissues (Fig. 2f). There were no statistically significant relationships between $\Sigma_{16} \mathrm{PAH}$ and $\Sigma$ aPAH wet weight concentration in the tested tissues and grebe body mass, but these two groups of compounds were related to lipid content in the muscle $(p<0.02)$, not in other tissues.

\section{Interspecies differences}

The examined species of birds demonstrated similar general wet weight levels of PAHs in their bodies (Table 2), indicating the highest values in the kidneys and lungs, which is usually observed in seabirds (Zhang et al. 2015). This may be due to the fact that the bird kidneys occupy up to about $20 \%$ of their body weight and play a key role in xenobiotic metabolism, whereas bird respiratory system is the largest area of the organism's interaction with airborne pollutants (Sanderfoot and Holloway 2017; Zhang et al. 2015). Our research showed some interspecies differences in PAH concentrations in bird 
Fig. 2 Tissue composition of $\Sigma$ PAHs (a, b), $\Sigma_{16}$ PAHs (c, d), and $\Sigma$ aPAHs $(\mathbf{e}, \mathbf{f})$ in birds

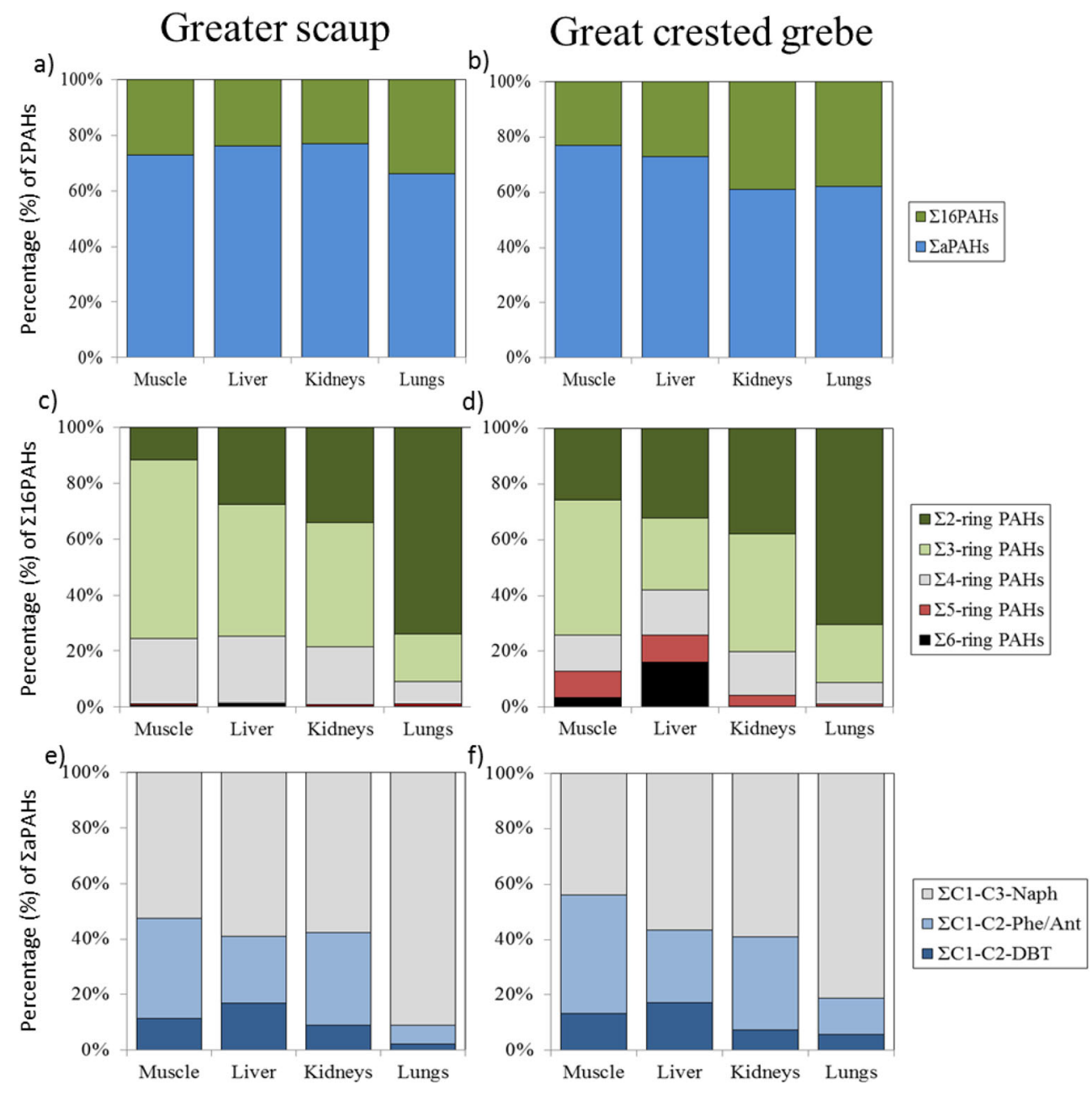

tissues. $\Sigma_{16} \mathrm{PAH}, \mathrm{\Sigma aPAH}$, and $\Sigma \mathrm{PAH}$ levels in the kidneys were about 1.5-3 times greater in grebe than in scaup and these differences were statistically significant. Whereas concentrations of $\Sigma$ aPAHs and $\Sigma$ PAHs in the lungs were found to be 1.5-fold greater in scaup than in grebe, these differences were not statistically significant. $\Sigma_{16} \mathrm{PAH}, \Sigma \mathrm{PPAH}$, and $\Sigma$ PAH levels in the muscle were nearly twofold greater in grebe than in scaup, and these differences for $\Sigma \mathrm{aPAH}$ and $\Sigma$ PAH concentrations were statistically significant. PAH levels in the liver did not differ between species. The same interspecies differences were observed for lipid-normalized concentrations of PAHs in tissues, except for the lungs, where the levels showed statistically significant differences, being about twofold greater in scaup than in grebe. The most likely cause for the occurrence of statistically insignificant differences in PAH levels between the birds was the large range of the obtained results, which in turn may be to the results of a relatively small number of individuals included in the study. However, it was not possible to obtain a larger number of the species in the time available. There were no significant differences in gender, body mass, and tissue lipid content between the birds (Table 1); therefore, these biological parameters did not affect interspecies differences in PAH levels. Furthermore, the birds could move between the two areas studied and it was considered that the regional differences are not significant. Whereas, it is possible that birds whose food base consists mostly of fish will be characterized by lower residues of PAHs in comparison with birds which feed on invertebrates (Kayal and Connell 1995; Lebedev et al. 1998). However, although scaup and grebe feed on different food types, no statistically significant differences were observed in the case of PAH levels in the liver of both species in the present study. Liver as the target tissue had been suggested to provide information regarding short-term exposure to PAHs in vertebrates due to its large and rapid detoxification capability (Custer et al., 2001; Hellou 1996; Roscales et al. 2011). Another explanation of differences between PAH concentrations in bird tissues could be metabolic capabilities. This can result in differences in PAH profiles between species (Fig. 2). To compare $\mathrm{PAH}$ composition in scaup and grebe tissues, the principal component analysis (PCA) was done (Fig. 3). PCA was based on a percentage share of native and alkylated groups of compounds in $\mathrm{SPAH}$ concentration in tissues. The data was auto-scaled with standard deviation set to 1 and mean value to 
Fig. 3 PCA analysis scores $(\mathbf{a}, \mathbf{c})$ and loadings $(\mathbf{b}, \mathbf{d})$ of PAH native and alkylated groups expressed as the percentage of $\mathrm{PAHH}$ in scaup $(\mathrm{S})$ and grebe $(\mathrm{G})$ muscle and liver a)

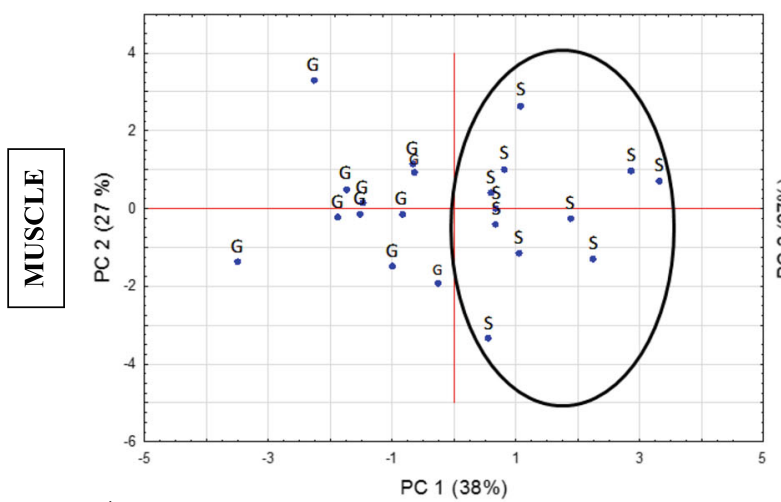

c)

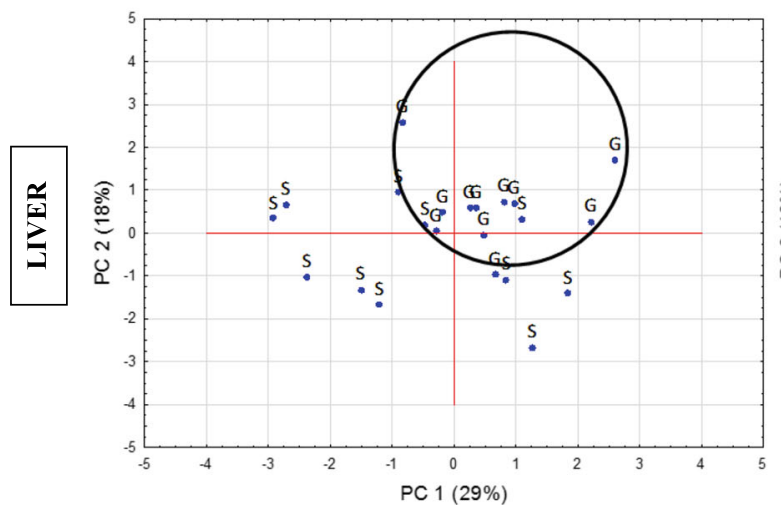

b)

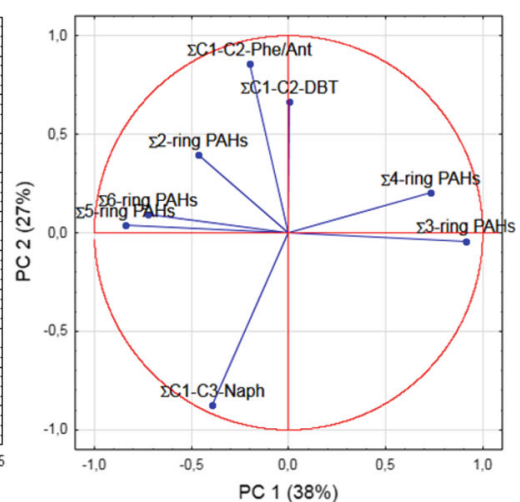

d)

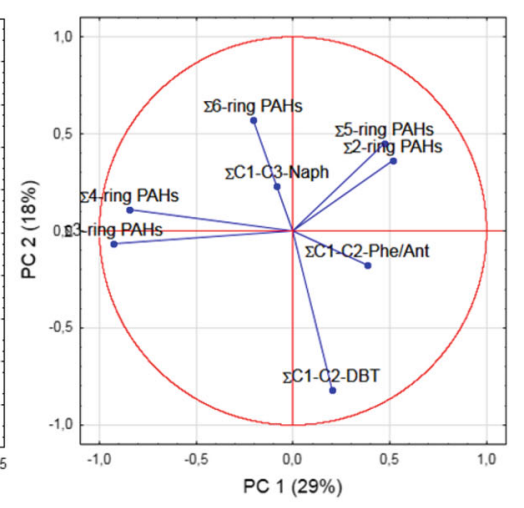

0 . Principal components (PCs) were extracted based on eigenvalues greater than 1 . Figure 3 graphically presents results of PCA for differences in PAH composition in the muscle and liver between birds. PCA graphic presentation for kidneys and lungs indicated that PAH composition was not different for both species, and therefore, it was not presented in the study. PCA for the muscle (Fig. 3a, b) identified two groups of birds, one included only grebe $(\mathrm{G})$ and second with scaup (S) specimens. The first group, including grebe specimens (G), was linked with loading of alkylated and native $\Sigma 2$-ring PAHs, $\Sigma 5$-ring PAHs, and $\Sigma 6$-ring PAHs. The second group, including scaup specimens, was associated with high positive loading of $\Sigma$ 3- and $\Sigma$ 4-ring PAHs. PCA for liver distinguished between the two groups of birds, i.e., scaup and grebe, but in less explicit way (Fig. 3c, d). Scaup group was clearly linked with $\Sigma$ 3- and $\Sigma 4$-ring PAHs, and $\Sigma$ C1-C2 DBT, but grebe group showed loadings of $\Sigma 2-, \Sigma 5$-, and $\Sigma 6$-ring PAHs, $\Sigma \mathrm{C} 1-\mathrm{C} 3 \mathrm{Naph}$, and $\Sigma \mathrm{C} 1-\mathrm{C} 2-\mathrm{Phe} /$ Ant. The most visible difference between both species in the muscle and liver profiles is in $\Sigma 2$ - and $\Sigma 5$-6-ring PAH contribution, and indicates other metabolic abilities of birds. All birds are equipped with a welldeveloped mixed-function oxidase (MFO) system that facilitates biotransformation and detoxification of exogenous chemicals, including PAHs (Albers and Loughlin 2003). The lower levels of 55 -6-ring PAHs in the scaup than in the grebe tissues suggest the first species has a higher biotransformation capacity than the second. Roscales et al. (2011) reported that the low presence of high molecular weight PAHs in the profile of petrel liver comparing to shearwaters analyzed in their studies may be explained by the greater capability of petrels to metabolize the larger PAH compounds. Similarly, according to Troisi et al. (2006), the absence of $\mathrm{B}(\mathrm{a}) \mathrm{P}$ from guillemot livers suggests this species has a high capacity for CYP4501A1-mediated B(a)P metabolism.

\section{PAH sources and risk assessment}

The specific pattern of PAH concentrations in the environment depends on the source of these compounds' contamination. The ratio of levels of PAHs with low molecular weight to that with high molecular weight is commonly used to distinguish between pyrolysis sources from petroleum or incomplete combustion sources of pollution (Fernandes et al. 1997). The concentrations of $\Sigma 2-3$-ring PAHs constituting more than $50 \%$ of $\Sigma \mathrm{PAHs}$ indicate a dominance of petroleum pollution and incomplete combustion, while levels of $\Sigma 4-6$ ring PAHs being of $>50 \%$ of $\Sigma \mathrm{PAHs}$ suggest a dominance of pyrolysis source. In the present study, the PAH composition in the tissues of both species indicates that petroleum and incomplete combustion can be the major sources of contamination. Similar data on the PAH sources in seabirds are widely reported (Custer et al. 2000; Taniguchi et al. 2009; Troisi et al. 2006). However, it should be noted that a different exposure to these contaminants through diet or different metabolic 
capabilities among species may alter the ratios of the PAHs that are pointing out different sources.

Avian exposure to PAHs seems to be related to contaminated diet, water, and air through inhalation and feather preening (Fernie et al. 2018). This study, in line with the majority of available reports (Kayal and Connell 1995; Rooscales et al., 2011) documented digestive tract as a base route of exposure to PAHs in seabirds. Available literature on PAH levels in birds is mainly based on their liver, muscle, fat tissue, eggs, and blood investigation (Kayal and Connell 1995; $\mathrm{N} f$ et al. 1992; Paruk et al. 2016; Taniguchi et al. 2009; Troisi et al. 2006). There are limited data on PAH concentrations in seabird lungs. Falkowska et al. (2017) examining PAH levels in the lungs and intestines of herring gull (Larus argentatus) reported that, despite the presence of PAHs in aerosol and the fact that they can be inhaled, the introduction with food is more significant for birds. However, the high levels of PAHs in the birds' lungs from this study point to it being the organ as a similarly important route for birds to be exposed to these compounds. The significant contribution of Naph and its alkylated homologs in the PAH profile in the lungs can be associated with some incomplete combustion processes, exhaust of ships, and evaporation or sublimation from crude oil and petroleum products in the investigated area ( $\mathrm{Jia}$ and Batterman 2010).

Contact with sufficient concentrations of PAHs may cause a broad spectrum of health effects in seabirds, from altering molecular and physiological processes to modifying hepatic and immune function, increasing physical deformities, reducing reproductive success and growth, and causing acute toxicity in birds covered with oil as an effect of oil spillage or even can lead to death (Albers 2006; Briggs et al. 1997; Bursian et al. 2017; Paruk et al. 2016). Although the acutely lethal effects of oil exposure in birds following catastrophic oil spills are well known (Balseiro et al. 2005; Newman et al. 2000), the PAH chronic exposure among marine birds occupying industrialized coastlines is undocumented. It has been suggested that the potential for mutagenic and carcinogenic effects is greatest among higher molecular weight PAHs (i.e., the 4- to 6-ring compounds and their alkylated forms) (Baird et al. 2007; Lee et al. 2017), but the level of exposure of PAHs at which the adverse effects do not occur in the bird (NOAEL) has not been estimated yet (E.U. 2008). Therefore, it can be stated that the low concentrations of PAHs in the birds from this study, and the particularly low concentrations of the harmful compounds, indicate a negligible exposer of birds to PAHs in the investigated region.

\section{Conclusion}

The study indicates that PAHs are present in the scaup and grebe tissues, and the levels and distribution of these compounds in birds depend mainly on the species specificity.
The different metabolic capabilities are the most probable hypothesis to explain the differences in PAH concentrations and profiles between the species. Due to the relatively low concentrations of measured pollutants and the small number of individuals to be investigated, further studies on PAH fate in bird are necessary.

Acknowledgments The authors thank Lena Szymanek (NMFRI) for helping in the map preparation.

Funding This research was funded by the Polish Ministry of Science and Higher Education.

Open Access This article is licensed under a Creative Commons Attribution 4.0 International License, which permits use, sharing, adaptation, distribution and reproduction in any medium or format, as long as you give appropriate credit to the original author(s) and the source, provide a link to the Creative Commons licence, and indicate if changes were made. The images or other third party material in this article are included in the article's Creative Commons licence, unless indicated otherwise in a credit line to the material. If material is not included in the article's Creative Commons licence and your intended use is not permitted by statutory regulation or exceeds the permitted use, you will need to obtain permission directly from the copyright holder. To view a copy of this licence, visit http://creativecommons.org/licenses/by/4.0/.

\section{References}

Albers PH (2006) Birds and polycyclic aromatic hydrocarbons. Avian Poult Biol Rev 17:125-140

Albers PH, Loughlin TR (2003) Effects of PAHs on marine birds, mammals, and reptiles. PAHs: an ecotoxicological perspective West Sussex, UK:243-262

Badzinski SS, Flint PL, Gorman KB, Petrie SA (2009) Relationships between hepatic trace element concentrations, reproductive status, and body condition of female greater scaup. Environ. Poll. 157: 1886-1893

Baird SJS, Baily EA, Vorhees DJ (2007) Evaluating human risk from exposure to alkylated PAHs in an aquatic system. Hum Ecol Risk Assess 13:322-338

Balseiro A, Espí A, Márquez I, Pérez V, Ferreras MC, Marín JFG, Prieto JM (2005) Pathological features in marine birds affected by the Prestige's oil spill in the north of Spain. J Wildl Dis 41:371-378

Boitsov S, Jensen HKB, Klungsoyr J (2009) Natural background and anthropogenic inputs of polycyclic aromatic hydrocarbons (PAH) in sediments of South-Western Barents Sea. Marin Environ Research 68:236-245

Briggs KT, Gershwin ME, Anderson DW (1997) Consequences of petrochemical ingestion and stress on the avian immune system. ICES J Mar Sci 54:718-725

Bursian SJ, Alexander CR, Cacela D, Cunningham FL, Dean KM, Dorr BS, Ellis CK, Godard-Codding CA, Guglielmo CG, Hanson-Dorr $\mathrm{KC}$, Harr KE, Healy KA, Hooper MJ, Horak KE, Isanhart JP, Kennedy LV, Link JE, Maggini I, Moye JK, Perez CR, Pritsos CA, Shriner SA, Trust KA, Tuttle PL (2017) Overview of avian toxicity studies for the Deepwater horizon natural resource damage assessment. Ecotoxicol Environ Saf 142:1-7

Custer DH, Custer CM, Hines RK, Sparks DW (2000) Trace elements, organochlorines, polycyclic aromatic hydrocarbons, dioxins, and 
furans in lesser scaup wintering on the Indiana Harbor canal. Environ Pollut 110(3):469-482

Dalsøren SB, Endresen O, Isaksen ISA, Gravir G, Sørgård E (2007) Environmental impact of the expected increase in sea transportation, with a particular focus on oil and gas scenarios for Norway and Northwest Russia. J Geophysical Research 112(D2). https://doi. org/10.1029/2005JD006927

EPA (2003) Procedures for the derivation of ESBs for the protection of benthic organisms: PAH mixtures. EPA/600/R-02/01 (United States Environmental Protection Agency Office of Research and Development, Washington, DC)

EPA (2004) Methods for the derivation of site-specific equilibrium partitioning sediment guidelines (ESGs) for the protection of benthic organisms: non-ionic organics. EPA/822/R/02/(US Environmental Protection Agency Office of Science and technology, Washington, DC)

EU (2008) European Union risk assessment report for coal-tar pitch, high temperature (CAS-no.: 65996-93-2, EINECS-no.: 266-028-2) (Final report, Environment). Institute for Health and Consumer Protection - European Chemicals Bureau. May, 2008

Falkowska L, Grajewska A, Staniszewska M, Nehring I, SzumiłoPilarska E, Saniewska D (2017) Inhalation-route of EDC exposure in seabirds (Larus argentatus) from the southern Baltic. Mar Poll Bull 117:111-117

Fernandes MB, Sicre MA, Boireau A, Tronczynski J (1997) Polyaromatic hydrocarbon (PAH) distribution in the Seine River and its estuary. Marin Poll Bull 34:857-867

Fernie KJ, Marteinson SC, Chen D, Eng A, Harner T, Smits JEG, Soos C (2018) Elevated exposure, uptake and accumulation of polycyclic aromatic hydrocarbons by nesting tree swallows (Tachycineta bicor) through multiple exposure routes in active mining-related areas of the Athabasca oil sands region. Sci Total Environ 624:250-261

Götz R, Bauer OH, Friesel P, Roch K (1998) Organic trace compounds in the water of the river Elbe near Hamburg. Part II. Chemosphere 36(9):2103-2118

Hellou J (1996) Polycyclic aromatic hydrocarbons in marine mammals, finfish, and molluscs. Environmental contaminants in wildlife: Interpreting tissues concentrations. Lewis Publisher, Boca Raton, 229-250

Ibadov NA, Suleymanov BA (2015) Determination of total hydrocarbons and alkyl PAHs in sediments from Absheron peninsula in Caspian Sea. Biological and Chemical Research 2015:111-122

Jaspers VLB, Covaci A, Voorspoels S, Dauwe T, Eens M, Schepens P (2006) Brominated flame retardants and organochlorine pollutants in aquatic and terrestrial predatory birds of Belgium: levels, patterns, tissue distribution and condition factors. Environ Poll 139:340-352

Jia C, Batterman S (2010) A critical review of naphthalene sources and exposures relevant to indoor and outdoor air. Int J Environ Res Public Health 7:2903-2939

Kayal S, Connell DW (1995) Polycyclic aromatic hydrocarbons in biota from the Brisbane River estuary, Australia. Estuar Coast Shelf Sci 40:475-493

Lebedev AT, Poliakova OV, Karakhanova NK, Petrosyan VS, Renzoni A (1998) The contamination of birds with organic pollutants in the Lake Baikal region. Sci Total Environ 212:153-162

Lee S, Hong S, Liu X, Kim C, Jung D, Yim UH, Shim WJ, Khim JS, Giesy JP, Choi K (2017) Endocrine disrupting potential of PAHs and their alkylated analogues associated with oil spills. Environ Sci Process Impacts 19(9):1117-1125

Lubecki L, Kowalewska G (2012) Indices of PAH origin - a case study of the Gulf of Gdańsk (SE Baltic) sediments. Polycycl Aromat Compd 32:335-363

Marchowski D, Neubauer G, Ławicki Ł, Woźniczka A, Wysocki A, Guentzel S, Jarzemski M (2015) The importance of non-native prey, the Zebra mussel Dreissena polymorpha, for the declining greater scaup Aythya marila: a case study at a key European staging and wintering site. PLoS One. https://doi.org/10.1371/journal.pone. 0145496

Martinez E, Gros M, Lacorte S, Barceló D (2004) Simplified procedures for the analysis of polycyclic aromatic hydrocarbons in water, sediments and mussels. J Chromatogr A 1047:181-188

Marvanová S, Vondrácek J, Penccíková K, Trilecová L, Krcmárr P, Topinka J, Nováková Z, Milcová A, Machala M (2008) Toxic effects of methylated benz[a]anthracenes in liver cells. Chem Res Toxicol 21(2):503-512

Mendel B, Sonntag N, Wahl J, Schwemmer P, Dries H, Guse N et al. (2008) Profiles of seabirds and waterbirds of the German north and Baltic Sea. Distribution, ecology and sensitivities to human activities within the marine environment. BFN. Bonn-Bad Godesberg

Morkune R, Lesutiene J, Bariseviciute R, Morkunas J (2016) Food sources of wintering piscivorous waterbirds in coastal waters: a triple stable isotope approach for the southeastern Baltic Sea. Estuar Coast Shelf Sci 171:41-50

Namieśnik J, Moncheva S, Park Y-S, Ham K-S, Heo B-K, Tashma Z, Katrich E, Gorinstein S (2008) Concentration of bioactive compounds in mussel Mytilus galloprovincialis as indicator of pollution. Chemosphere 73:938-944

Newman SH, Anderson DW, Ziccardi MH, Trupkiewiecz JG, Tseng FS, Chrostopher MM, Zinkl JG (2000) An experimental soft-release of oil-spill rehabilitated American coots (Fulica americana): II. Effects on health and blood parameters. Environ Pollut 107:295-304

Näf C, Broman D, Brunstrom B (1992) Distribution and metabolism of polycyclic aromatic hydrocarbons (PAHs) injected into eggs of chicken (Gallus domesticus) and common eider duck (Somateria mollissima). Environ Toxicol Chem 11(11):1653-1660

Paruk JD, Adams EM, Uher-Koch H, Kovach KA, Long D, Perkins C, Schoch N, Evers DC (2016) Polycyclic aromatic hydrocarbons in blood related to lower body mass in common loons. Sci Total Environ 565:360-368

Pérez C, Velando A, Munilla I, López-Alonso M, Oro D (2008) Monitoring polycyclic aromatic hydrocarbon pollution in the marine environment after the prestige oil spill by means of seabirds analysis. Environ. Sci. Technol. 42:707-713

Piersma T, Lindeboom R, Eerden MR (1988) Foraging rhythm of great crested grebes Podiceps cristatus adjusted to diel variations in the vertical distribution of their prey Osmerus eperlanus in a shallow eutrophic lake in the Netherlands. Oecologia 76:481-486

Roscales JL, González-Solís J, Calabuig P, Jiménez B (2011) Interspecies and spatial trends in polycyclic aromatic hydrocarbons (PAHs) in Atlantic and Mediterranean pelagic seabirds. Environ Poll 159: 2899-2905

Sanderfoot OV, Holloway T (2017) Air pollution impacts on avian species via inhalation exposure and associated outcomes. Environ Res Lett 12:083002. https://doi.org/10.1088/1748-9326/aa8051

Stempniewicz L, Meissner W (1999) Assessment of zoobenthos biomass consumed early by diving duck wintering in the Gulf of Gdańsk (southern Baltic Sea). Ornis Svecica 9:143-154

Taniguchi S, Montone RC, Bícero MC, Calabuono FI, Weber RR, Sericano JL (2009) Chlorinated pesticides, polychlorinated biphenyls and polycyclic aromatic hydrocarbons in the fat tissue of seabirds from King George Island, Antarctica. Mar. Poll. Bull. 58:129133

Tomza-Marciniak A, Pilarczy B, Witczak A, Rząd I, Pilarczyk R (2019) PCB residues in the tissues of sea ducks wintering on the south coast of the Baltic Sea, Poland. Environ Sci Pollut Res 26:11300-11313

Troisi GM, Bexton S, Robinson I (2006) Polyaromatic hydrocarbon and PAH metabolite burdens in oiled common guillemots (Uria aalge) stranded on the east coast of England (2001-2002). Environ Sci Technol 40:7938-7943

Ulenaers P, Vessem J (1994) Impact of great crested grebes (Podiceps cristatus L.) on fish ponds. Hydrobiologia 279/280:353-366 
Verbrugge LA, Giesy JP, Verbrugge DA, Woodin BR, Stegeman JJ (2001) Catalytic and immunochemical properties of hepatic cytochrome P450 1A in three avian species treated with naphthoflavone or isosafrole. Comp Biochem Physiol, Part C 130:67-83

Waszak I, Dabrowska H, Warzocha J (2019) Assessment of native and alkylated polycyclic aromatic hydrocarbons (PAHs) in sediments and mussels (Mytilus spp.) in the southern Baltic Sea. Environ Sci: Processes Impacts 21:514-527

Zhang Y, Cui B, Zhang Q, Liu X (2015) Polycyclic aromatic hydrocarbons in the food web of coastal wetlands: distribution, sources and potential toxicity. Clean - Soil, Air, Water 43(6):881-891
Zhou JB, Wang TG, Huang YB, Mao T, Zhong NN, Zhang Y et al (2005) Concentration and distribution characterization of polycyclic aromatic hydrocarbons in airborne particles with different sizes. Environ. Sci. 26:40-44

Publisher's note Springer Nature remains neutral with regard to jurisdictional claims in published maps and institutional affiliations. 